\title{
Epidermoid cyst of the posterior fossa: a case report
}

Cisto epidermoide da fossa posterior: relato de caso

\author{
Eduardo Cambruzzi ${ }^{1}$; Karinelli Presa ${ }^{2}$; Luciano Carvalho Silveira ${ }^{3}$; Gerson Evandro Perondi ${ }^{4}$
}

key words
Epidermal cyst
Brain neoplasms
Cerebellopontine angle
Pathology
Central nervous system
cysts

\section{abstract}

Epidermoid cysts of the central nervous system are uncommon conditions, which are frequently located in the cerebellopontine angle and around the pons. They are covered with keratinized squamous epithelium and keratin lamella, which give its contents a soft, white-pearly appearance. Epidermoid cysts are mostly originated from malformations, presumably associated with surface elements of the nervous system ectoderm during the closure of the neural groove or formation of secondary cerebral vesicles. The authors describe a case of epidermoid cyst in the posterior fossa causing hydrocephalus and review morphologic and diagnostic criteria of this lesion.

\section{resumo}

Os cistos epidermoides do sistema nervoso central (SNC) são condições incomuns, estando localizados mais frequentemente no ângulo pontocerebelar e ao redor da ponte. Eles são revestidos por epitélio escamoso queratinizado e lamelas de queratina, tornando seu conteúdo branco-perolado e pastoso. Os cistos epidermoides são, na maioria das vezes, originados de malformações, possivelmente associados ao entremeio de elementos superficiais do ectoderma do SNC durante o fechamento da placa neural, ou formação das vesículas cerebrais secundárias. Os autores descrevem um caso de cisto epidermoide da fossa posterior determinando hidrocefalia e revisam critérios morfológicos e diagnósticos dessa lesão.

\section{unitermos}

Cisto epidérmico

Neoplasias encefálicas

Ângulo cerebelopontino

Patologia

Cistos do sistema nervoso central 


\section{Introduction}

Epidermoid cysts comprise $0.2 \%-1.8 \%$ of primary intracranial expanding lesions and are four to nine times as common as dermoid cysts. The most common location for epidermoid cysts is the cerebellopontine angle (40\%-50\%), where they represent the third most frequent tumor in this location, after acoustic schwannoma and meningioma. Epidermoid cyst may also occur in the fourth ventricle (17\%) and in the sellar/parasellar regions (10\%-15\%). Less common location includes the cerebral hemispheres, brainstem, skull and spine ${ }^{(11,14)}$.

Epidermoid cysts are generally located off the midline, and arise from ectodermal inclusion during neural tube closure in the third-fifth week of embryogenesis. Epithelial rests may be transplanted to regions such cerebellopontine angle by the lateral migrating otic capsule or developing neurovasculature. The lesions grows to encase vessels and nerves, and is interior consists of layered anucleate squames produced by a well-differentiated squamous epithelium, often with keratohyaline granules. These cysts may rupture to cause an exuberant inflammatory reaction in the surrounding parenchyma ${ }^{(4,8,11,14)}$.

The authors describe a case of epidermoid cyst arising in the posterior fossa determining hydrocephalus in a 65 years old female patient.

\section{Case report}

Female patient, 65 years old, was admitted to the emergency department presenting mental confusion, decreased sensorium, headache, and vomiting, with a score of 4 on the scale of Glasgow, beginning three months ago. The clinical history revealed changes in the sensorium beginning three months. The computed tomography and magnetic resonance imaging (Figure 1) showed cystic lesion in the posterior fossa, with compressive effect on the fourth ventricle, measuring $4 \times 3.2 \mathrm{~cm}$, and determining dilatation of the third and lateral ventricles (hydrocephalus).

The initial procedure consisted of placing enteric ventricular drain, with subsequent endoscopic ventriculostomy. With the stabilization of the patients clinical conditions, it was determined the resection of the lesion. At the opening of the skull, the process proved to be intact, light gray, tense, adhered to adjacent tissues, being removed by curettage. At gross examination, the piece consisted of several irregular fragments of cloth, light-gray, elastic, together weighing $12 \mathrm{~g}$ and measuring the largest $1.8 \times 1.5 \times 1 \mathrm{~cm}$. On microscopic evaluation, a cystic lesion occupied by keratin lamellae was identified, showing thin wall consisted of loose connective tissue and lined by keratinized squamous epithelium with keratohyaline granules (Figure 2). The epithelial lining showed positive immunoexpression for cytokeratin (AE1/AE3). The microscopic examination of the process associated with clinical data was consistent with an epidermoid cyst. Four months after the surgery, the patient did not have clinical or radiological signs of recurrence of the lesion.

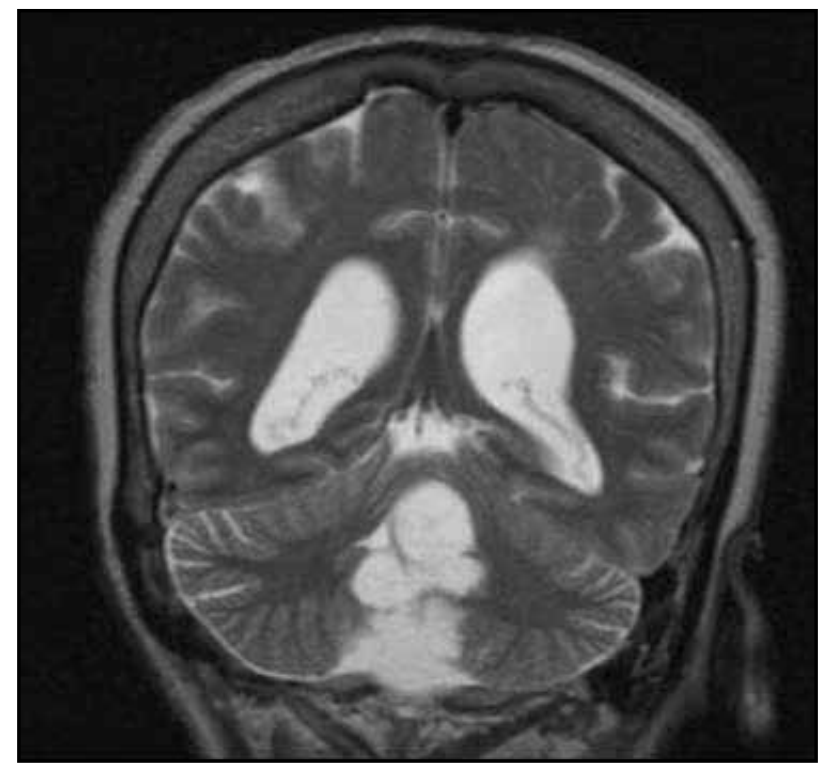

Figure 1 - Preoperative magnetic resonance imaging showing a hyperdense mass in the posterior fossa and hydrocephalus

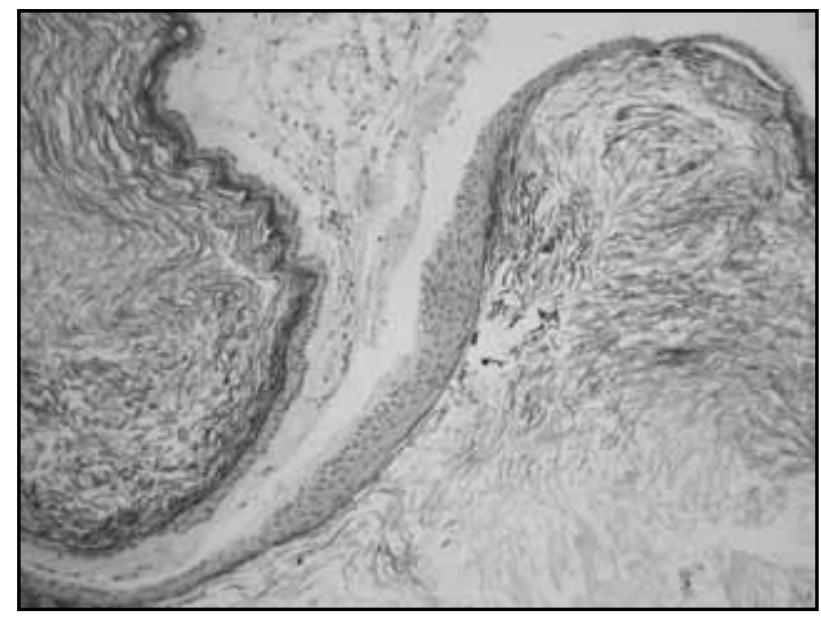

Figure 2 - Epidermoid cyst: cystic lesion lined by a thin layer of squamous epithelium and filled with keratinous debris (hematoxylin-eosin, 200x) 


\section{Discussion}

Epidermoid cysts are developmental lesions that result from embryologic displacement of ectoderm into the meninges, ventricles, or rarely into the parenchyma of the brain. Rarely, these lesions arise from implants of epithelium carried into the meninges during percutaneous aspiration of the subdural or subarachnoid space. A proportion of spinal epidermoid cysts, especially those in the lumbosacral region, occur in conjunction with spina bifida or diastematomyelia ${ }^{(3,11,14)}$.

Intracranial epidermoid cysts account for only $1 \%$ of all intracranial expanding lesions if suprasellar examples are excluded. The cerebellopontine angle and parapontine region are the most common intracranial site for epidermoid cysts. Less frequently, they may occur in the cerebral hemispheres, the lateral ventricles, cisterns at the base of the brain and in the orbits. Intraspinal lesions are less common. Rarely, epidermoid cysts arise in the cranial diploe of the middle ear region or frontal bone, where they present as a lytic defect. Unlike dermoid cysts, epidermoid cysts often occur laterally, without a preference for midline

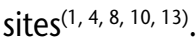

The symptoms of an epidermoid cyst are generally those of a slowly enlarging mass. The lesions tend to surround and envelope, rather than displace, regional structures. The leakage of cyst contents produces chemical irritation of the leptomeninges or ependyma ${ }^{(1,4,9,10,14)}$.

In the actual report, the authors describe an epidermoid cyst involving predominantly the midline of the posterior fossa, adhered to adjacent structures, and determining hydrocephalus in a female patient presenting mental confusion and decreased sensorium.

Due to their discretness, generally extra-axial position, and neuroradiologic signal characteristics of keratinaceous debris, epidermoid cysts are often diagnose before surgery. Depending up the amount of lipid in their contents, the lesions exhibit a variable sign on MRI, appearing as either bright or whit (when lipid content is high) in T1-weighted images, or black (if lipid content is low). On computed tomography (CT) scans, most epidermoid cysts are welldefined hypoattenuated masses. Most epidermoid cysts do not enhance, although some minimal rim enhancement

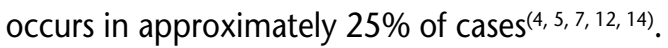

On gross examination, they are rounded and slightly fluctuant masses with a smooth whitish capsule. The uniloculate, thin-walled epidermoid cyst has a pearly sheen due to its thin wall and content of compact flaky keratin. Epidermoid cysts vary in size from a few milimetres to over $10 \mathrm{~cm}$ in diameter $(4,8,10,13)$.

On microscopic examination, the epidermoid cysts consist of layered anucleate squames produced by a thin, well-differentiated squamous epithelium, often with keratohyaline granules. The lamellated keratin fills the cyst lumen. The wall is composed with connective tissue. Although epidermoid cysts are benign lesions, rare transformation to squamous carcinoma has been reported. Calcification is uncommon. The lining epithelium of epidermoid cyst is immunoreactive for cytokeratins and epithelial membrane antigen (EMA). In contrast to cysts of neuroglial origin there is no immunoreactivity of the lining epithelium with antibodies to glial fibrillary acidic protein

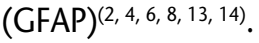

In most locations, epidermoid cysts are distinctive lesions. In the suprasellar region, the differential diagnosis includes craniopharyngioma. The delicate epithelium of an epidermoid cyst is distinguished from the thicker, complex, and palisade epithelium of adamantinomatous craniopharyngioma. The epithelium of the papillary craniopharyngioma is generally thick and disposed in crude papillae with fibrovascular core. Papillary craniopharyngioma lacks keratohyaline granules and anucleate squames. Dermoid cysts are more common in childhood and lie in the midline, being related to fontanel, the fourth ventricle, or the spinal canal. The irregularly thickened wall of dermoid cyst contains adnexal structures, such as hair follicles, sebaceous glands, and fibroadipose tissue. An epidermoid cyst can resemble too teratoma, or Rathke cleft cyst with extensive squamous metaplasia $(4,10,12,14)$.

The ideal treatment for craniospinal epidermoid cysts is complete surgical removal, but in many cases dense adherence of the capsule to adjacent brain, vessels, cord or nerve roots can limit the complete resection of the cyst wall. The most frequent postoperative complication following resection of intradural epidermoid cysts is a chemical meningitis due to leakage of keratin into the cerebrospinal fluid (CSF) pathways at the time of surgery ${ }^{(1,4,10-13)}$. 


\section{References}

1. AKHADDAR, A. et al. Cerebellar abscess secondary to occipital dermoid cyst with dermal sinus: case report. Surg Neurol, v. 58, p. 266-70, 2002.

2. ASAHI, T. et al. Malignant transformation of cerebellopontine angle epidermoid. J Clin Neurosci, v. 21, p. 383-7, 2001.

3. BOYD, H. R. latrogenic intraspinal epidermoid. Report of a case. J Neurosurg, v. 24, p. 105-7, 1996.

4. BURGER, P. C.; SCHEITHAUER, B. W. Benign cystic lesions. In: BURGER, P. C.; SCHEITHAUER, B. W. Tumors of the central nervous system. Armed Forces Institute of Pathology - Atlas of Tumor Pathology. v. 7. Washington, DC: ARP Press, 2007. p. 471-90.

5. CHEN, S. et al. Quantitative MR evaluation of intracranial epidermoid tumors by fast fluid-attenuated inversion recovery imaging and echo-planar diffusion weighted imaging. Am J Neuroradiol, v. 22, p. 1089-96, 2001.

6. GE, P. et al. Recurrent epidermoid cyst with malignant transformation into squamous cell carcinoma. Neurol Med Chir, v. 49, p. 442-4, 2009.

7. GOEL, A. et al. Lateral supracerebellar transtentorial approach to a middle fossa epidermoid tumor. J Clin Neurosci, v. 17, p. 372-3, 2010.
8. GORMLEY, W. B. et al. Craniocerebral epidermoid and dermoid tumors: a review of 32 cases. Acta Neurochir (Wien), v. 128, p. 115-21, 1994.

9. GUTTAL, K. S. et al. Trigeminal neuralgia secondary to epidermoid cyst at the cerebellopontine angle: case report and brief overview. Odontology, v. 97, p. 54-6, 2009.

10. LAKHDAR, A et al. Epidermoid cyst of the cerebellopontine angle. A surgical series of 10 cases and review of the literature. Neurochirugie, v. 49, p. 13-24, 2003.

11. MOHANTY, A. et al. Experience with cerebellopontine angle epidermoids. Neurosurgery, v. 40, p. 24-30, 1997.

12. OSBORN, A. G. et al. Intracranial cysts: radiologicpathologic correlation and imaging approach. Radiology, v. 239, p. 650-64, 2006.

13. SOUZA, C. E. et al. Cerebellopontine angle epidermoid cysts: a report on 30 cases. J Neurol Neurosurg Psychiatry, v. 52, p. 986-90, 1989.

14. VINCHON, M. et al. Intradural epidermoid cysts of the cerebellopontine angle: diagnosis and surgery. Neurosurgery, v. 36, p. 52-7, 1995. 